\title{
MENU GIZI SEIMBANG DAN PEMERIKSAAN KESEHATAN PADA BALITA DI POSKESDES RIA-RIA KECAMATAN POLLUNG KABUPATEN HUMBANG HASUNDUTAN
}

\author{
Fransiska $^{1}$, Mayes $^{2}$ \\ ${ }^{1,2}$ STIKes Kesehatan Baru Doloksanggul \\ fransiska.debataraja@stikeskb.ac.id, mayes.simamora@stikeskb.ac.id
}

\begin{abstract}
ABSTRAK
Menu makanaan seimbang merupakan susunan makanan yang dimakan sehari hari untuk mencapai kecukupan gizi dalam tubuh yang terdiri dari beranekaragam makanan dalam jumlah dan proporsi yang sesuai, sehingga memenuhi kebutuhan gizi seseorang guna pemeliharaan dan perbaikan sel-sel tubuh dan proses kehidupan serta pertumbuhan dan perkembangan. Pada masa balita hal ini menu seimbang diperlukan untuk periode perkembangan fisik dan mental yang pesat. Pada masa ini, otak balita telah siap menghadapi berbagai stimulasi seperti belajar berjalan dan berbicara lebih lancar. Metode pengabdian masyarakat ini dengan cara kualitatif dan kuantitatif, wawancara dan observasi ke rumah rumah penduduk. Hasil pengabdian masyarakat menunjukkan masyarakat mulai memahami penting nya menu seimbang dan melakukan pemeriksaan kesehatan pada anak balitanya. Diharapkan masyarakat secara kontiniu melakukan pemeriksaan kesehatan pada balita dan mempertahankan asupan meni seimbang pada balita nya.
\end{abstract}

Kata Kunci: menu seimbang, pemeriksaan fisik balita

\section{ABTRACT}

A balanced diet is the arrangement of food eaten daily to achieve nutritional adequacy in the body consisting of a variety of foods in appropriate quantities and proportions, so as to meet one's nutritional needs for the maintenance and repair of body cells and life processes as well as growth and development. In infancy this balanced diet is necessary for a period of rapid physical and mental development. At this time, the toddler's brain is ready for various stimulations such as learning to walk and speak more fluently. This community service method uses qualitative and quantitative methods, interviews and observations in people's homes. The results of community service show that the community has begun to understand the importance of a balanced diet and to carry out health checks on their children. It is hoped that the community will continue to carry out health checks on toddlers and maintain a balanced intake of meni for their children.

Keywords: balanced menu, toddler physical examination

\section{PENDAHULUAN}

Masa balita (bawah lima tahun) dan batita (bawah tiga tahun) adalah periode penting dalam proses tumbuh kembang seorang anak. Pertumbuhan dan perkembangan di masa itu menjadi patokan keberhasilan anak di periode selanjutnya. Masa ini tumbuh kembang seorang anak berlangsung sangat cepat dan tidak akan pernah terulang, maka dari itu sering disebut dengan golden age atau masa keemasan. Namun, tantangan pada masa golden age ini adalah kecukupan gizi balita. Apabila balita tidak cukup energy dan gizi, 
maka sangat rentan mengalami gangguan kesehatan berupa malnutrisi (Cut, R. Azria, \& Husnah. (2015). Malnutrisi atau gizi buruk dan kekurangan energi kronis pada seribu hari pertama kehidupan anak dapat menyebabkan gangguan pertumbuhan yang sulit diperbaiki ketika telah dewasa, seperti gangguan kognitif yang dapat mempengaruhi kinerja belajar di sekolah dan ketika bekerja. Anak stunting mengalami gangguan pola makan yaitu selera makan berkurang sehingga pertumbuhan sel otak yang seharusnya berkembang sangat pesat dalam dua tahun pertama kehidupan terhambat ( Wachdani, R., Abidin, Z., \& Yaqin, M. A. (2012). Hal tersebut berdampak pada pertumbuhan mental dan fisik sehingga potensi anak di masa golden age tidak berkembang dengan maksimal.

Faktor-faktor yang mempengaruhi status gizi balita secara umum dipengaruhi oleh dua faktor yaitu faktor langsung dan faktor tidak langsung. Faktor langsung atau faktor dari individu atau anak yaitu asupan makanan dan penyakit (Diare dan Infeksi Saluran Pernapasan Akut/ISPA). Faktor tidak langsung atau faktor dari keluarga yaitu ketersediaan pangan, sanitasi lingkungan, pola asuh orang tua didalamnya adalah pola pemberian makan, pengetahuan, sikap, keterampilan, dan pelayanan kesehatan ( Asosiasi Dietisien Indonesia (Asdi), Ikatan Dokter Anak Indonesia (IDAI) \& Persatuan Ahli Gizi Indonesia (PERSAGI). 2014).

Pola makan merupakan suatu kebiasaan menetap dalam hubungan dengan konsumsi makan yaitu berdasarkan jenis bahan makanan : makanan pokok, sumber protein, sayur, buah, dan berdasarkan frekuensi: harian, mingguan, pernah, dan tidak pernah sama sekali. Dalam hal pemilihan makanan dan waktu makan manusia dipengaruhi oleh usia, selera pribadi, kebiasaan, budaya dan sosial ekonomi. Gizi seimbang adalah susunan makanan sehari-hari yang mengandung zat-zat gizi dalam jenis dan jumlah yang sesuai dengan kebutuhan tubuh, dengan memperhatikan prinsip keanekaragaman atau variasi makanan, aktivitas fisik, kebersihan, dan berat badan ideal (Asosiasi Dietisien Indonesia (Asdi), Ikatan Dokter Anak Indonesia (IDAI) \& Persatuan Ahli Gizi Indonesia (PERSAGI). 2014).

Pengetahuan dan tindakan merupakan komponen dan prasyarat penting terjadinya perubahan sikap dan perilaku gizi untuk menurunkan masalah gizi. Pengetahuan mengenai gizi menyumbangkan pengaruh yang cukup besar terhadap status gizi seseorang. Tingkat pengetahuan gizi seseorang akan mempengaruhi tindakan. Kurangnya pengetahuan mengenai gizi akan mengurangi kemampuan seseorang dalam menerapkan informasi gizi dalam kehidupannya sehari-hari. Pengetahuan atau tingkah laku model yang terdapat dalam media audio visual akan merangsang masyarakat untuk meniru atau menghambat tingkah laku yang tidak sesuai dengan tingkah laku yang ada di media audio visual. Sedangkan sikap atau respon yang masih tertutup dari seseorang terhadap suatu objek dipengaruhi oleh beberapa faktor, salah satunya yaitu media massa. Peran ibu sebagai pengasuh dan pendidik yang berperanan penting dalam pemenuhan gizi pada anak terutama usia 1-5 tahun. Pemenuhan gizi pada balita tidak cukup hanya dengan memberikan PMT saja, tetapi juga dengan peningkatan pengetahuan gizi keluarga. Peningkatan pengetahuan gizi telah dilakukan oleh dinas kesehatan seperti penyuluhan gizi, keluarga sadar gizi, dan pemberian makanan tambahan, namun dampaknya belum mampu menekan angka kejadian gizi kurang dan gizi buruk pada balita. Orangtua bertanggungjawab terhadap masalah makanan di rumah, jenis-jenis makanan apa yang tersedia dan kapan makanan tersebut disajikan.Tenaga kesehatan diharapkan mampu memberikan penyuluhan dan mengikutsertakan orang tua, anggota keluarga, serta pengasuh anak dalam kegiatan pembinaan kesehatan menyangkut perbaikan gizi, perbaikan kesehatan lingkungan, maupun tumbuh kembang anak ( Margawati, A., \& Astuti, A. M. (2018).

Berdasarkan data kematian anak menurut World Health Organization (WHO), dikemukan penyebab kematian tersebut yaitu komplikasi kelahiran prematur, pneumonia, 
asfiksia lahir, diare dan malaria. Diperkirakan sekitar $45 \%$ dari seluruh kematian anak terkait dengan gizi buruk sehingga membuat anak lebih rentan terhadap penyakit. Diantara 33 provinsi di Indonesia, 18 provinsi memiliki prevalensi gizi kurang di atas angka prevalensi nasional yaitu berkisar antara $21,2 \%$ sampai dengan $33,1 \%$. sumutera utara merupakan urutan ke 16 diantara 18 provinsi tersebut (5). Sedangkan Proporsi gizi kurang sebesar 13,9\% lebih tinggi dibandingkan pada tahun 2010 dan 2007 yaitu sebesar 13,0\%. Sedangkan proporsi gizi buruk pada tahun 2013 mengalami kenaikan yaitu sebesar 5,7\% dibandingkan dari tahun sebelumnya yaitu pada tahun 2010 sebesar 4,0\% dan pada tahun 2007 sebesar $5,4 \%$.

\section{METODE}

Metode kuantitatif dan kualitatif dalam proses pengumpulan data teknik observasi dan wawancara. Observasi dilakukan dengan mengunjungi rumah rumah penduduk yang memiliki balita dan melihat secara langsung bagaimana ibu ibu yang mempunyai balita memberikan menu kepada balita nya.

\section{HASIL}

\begin{tabular}{|l|l|l|l|l|}
\hline \multirow{2}{*}{ No Nama } & \multicolumn{1}{|c|}{ Umur Bayi } & \multicolumn{2}{c|}{ Hasil } \\
\cline { 4 - 5 } & & & \multicolumn{1}{c|}{ BB } \\
\hline 1 & Rola Hutabarat & 3 Bulan & $69 \mathrm{~cm}$ & $8 \mathrm{Kg}$ \\
\hline 2 & Risma Sinaga & 4 Bulan & $71 \mathrm{~cm}$ & $9 \mathrm{Kg}$ \\
\hline 3 & Sussi L. Toruan & 8 Bulan & $80 \mathrm{~cm}$ & $10 \mathrm{Kg}$ \\
\hline 4 & Lampita Munthe & 3 Bulan & $83 \mathrm{~cm}$ & $12 \mathrm{Kg}$ \\
\hline 5 & Lamtiur Purba & 3.6 Tahun & $81 \mathrm{~cm}$ & $10 \mathrm{Kg}$ \\
\hline 6 & Martina Simanullang & 1 Tahun & $78 \mathrm{~cm}$ & $8.2 \mathrm{Kg}$ \\
\hline 7 & Mayanti Sihotang & 1.5 Tahun & $75 \mathrm{~cm}$ & $8.7 \mathrm{Kg}$ \\
\hline 8 & Riris Marmada & 2 Tahun & $78 \mathrm{~cm}$ & $9.2 \mathrm{Kg}$ \\
\hline 9 & Dea Aulia Siregar & 1.5 Tahun & $75 \mathrm{~cm}$ & $6.5 \mathrm{Kg}$ \\
\hline 10 & Eva Nababan & 3.5 Tahun & $90 \mathrm{~cm}$ & $14 \mathrm{Kg}$ \\
\hline 11 & Gomrita Siregar & 1 Tahun & $75 \mathrm{~cm}$ & $91 \mathrm{Kg}$ \\
\hline 12 & Morika Sireegar & 4 Bulan & - & $6.4 \mathrm{Kg}$ \\
\hline 13 & Natasya Siregar & 2 Tahun 10 Bulan & $94 \mathrm{~cm}$ & $14 \mathrm{Kg}$ \\
\hline 14 & Ria Renata Lumban Gaol & 5 Tahun & $99 \mathrm{~cm}$ & $14 \mathrm{Kg}$ \\
\hline 15 & Suci L. Gaol & 1 Tahun & $76 \mathrm{~cm}$ & $7.7 \mathrm{Kg}$ \\
\hline 16 & Steeven & 3.5 Tahun & $93 \mathrm{~cm}$ & $13 \mathrm{Kg}$ \\
\hline 17 & Syalisa & 2 Tahun & $78 \mathrm{Cm}$ & $10 \mathrm{Kg}$ \\
\hline 18 & Ria Banjarnahor & 2.7 tahun & $83 \mathrm{Cm}$ & $10 \mathrm{Kg}$ \\
\hline 19 & Alvriando Munthe & 2.2 Tahun & $78 \mathrm{~cm}$ & $92 \mathrm{Kg}$ \\
\hline 20 & Binson Siringo-Ringo & 1.6 Tahun & $77 \mathrm{~cm}$ & $93 \mathrm{Kg}$ \\
\hline 21 & Caca L. Gaol & 10 Bulan & $61 \mathrm{~cm}$ & $7.3 \mathrm{Kg}$ \\
\hline 22 & Januarius L. Gaol & 2.6 Tahun & $75 \mathrm{~cm}$ & $10 \mathrm{Kg}$ \\
\hline 23 & Ezra Y. Panjaitan & 1.5 Tahun & $8 \mathrm{Kg}$ \\
\hline
\end{tabular}




\section{PEMBAHASAN}

Pola menu makanan adalah cara memilih hidangan yang terdiri dari olahan bahan pangan untuk dikonsumsi. Dalam menentukan pola makan balita, seseorang harus memiliki pengetahuan mengenai bahan makanan, jumlah kalori yang dikandung setiap makanan, pengetahuan hidangan dan kebutuhan harian balita terhadap energi, karbohidrat, lemak dan protein (Santoso, 1999). Pola makan seimbang adalah kebiasaan makan yang memenuhi kebutuhan semua zat gizi, seperti zat tenaga (karbohidrat dan lemak), zat pembangun (protein) dan zat pengatur (vitamin dan mineral). Pola makan seimbang haruslah bervariasi dan seimbang dari kuantitas maupun kualitas makanan itu sendiri. Bervariasi yang dimaksud yaitu di dalam porsi makanan ada semua zat gizi dan kuantitasnya seimbang, sehingga tidak ada satu jenis zat gizi yang berlebihan dalam porsi makanan. Pola makan dipengaruhi oleh beberapa hal, antara lain adalah kebiasaan kesenangan, budaya, agama, taraf ekonomi, lingkungan alam, dan sebagainya. Sejak zaman dahulu kala, makanan selain untuk kekuatan/pertumbuhan, memenuhi rasa lapar, dan selera, juga mendapat tempat sebagai lambang yaitu lambang kemakmuran, kekuasaan, ketentraman dan persahabatan. Semua faktor di atas bercampur membentuk suatu ramuan yang kompak yang dapat disebut pola konsumsi (Santoso dan Ranti, 2004). Pada rentang usia 3-5 tahun kerap terjadi anak menolak makanan yang tidak disukai dan hanya memilih makanan yang disukai sehingga perlu diperkenalkan kepada mereka beranekaragam makanan. Pada usia ini anak sudah harus makan seperti polamakan keluarga, yaitu: sarapan, makan siang, makan malam dan 2 kali selingan. Porsi makan pada usia ini setengah dari porsi orang dewasa. Memasuki usia 1 tahun pertumbuhan mulai lambat dan permasalahan mulai sulit makan muncul. Sementara itu aktivitas mulai bertambah dengan bermain sehingga makan dapat dilakukan sambal bermain. Namun selanjutnya akan lebih baik kalau makan dilakukan bersama seluruh anggota keluarga dengan mengajarkannya duduk bersama di meja makan. Beberapa hal yang harus diperhaikan dalam pemberian makan anak usia 1-5 tahun:

a. Selalu variasikan makanan yang diberikan meliputi makanan pokok, lauk pauk, sayuran dan buah. Usahakan protein yang diberikan juga berganti sehingga semua zat gizi terpenuhi.

b. Variasikan cara mengolah sehingga semua bahan makanan dapat masuk, misalnya anak tidak mau makanbayam maka bayam dapat dibuat dalam telur dadar.

c. Berikan air putih setiap kali habis makan.

d. Hindari memberikan makanan selingan mendekati jam makan utama.

e. Ketika masuk usia 2 tahun jelaskan manfaat makanan yang harus dimakan sehingga dapat mengurangi rasa tidak sukanya.

Faktor-faktor Yang Mempengaruhi Pola Makan Gizi Seimbang

a. Pengetahuan ibu

Pengetahuan tentang bahan makanan yang bergizi masih kurang maka pemberian makanan untuk keluarga biasa dipilih bahan-bahan makanan yang hanya dapat mengenyangkan perut saja tanpa memikirkan apakah makanan itu bergizi atau tidak, sehingga kebutuhan gizi energi dan zat gizi masyarakat dan anggota keluarga tidak tercukupi. Menurut Suhardjo (1989), bila ibu rumah tangga memiliki pengetahuan gizi yang baik ia akan mampu untuk memilih makanan-makanan yang bergizi untuk dikonsumsi.

b. Pendidikan ibu

Peranan ibu sangat penting dalam penyediaan makanan bagi anaknya. Pendidikan ibu sangat menentukan dalam pilihan makanan dan jenis makanan yang dikonsumsi oleh 
anak dan anggota keluarganya lainnya. Pendidikan gizi ibu bertujuan meningkatkan penggunaan sumber daya makanan yang tersedia. Hal ini dapat diasumsikan bahwa tingkat kecukupan zat gizi pada anak tinggi bila pendidikan ibu tinggi (Depkes RI, 2000)

c. Pendapatan Keluarga

Pendapatan salah satu faktor dalam menentukan kualitas dan kuantitas makanan.Tingkat pendapatan ikut menentukan jenis pangan yang akan dibeli dengan tambahan uang tersebut. Orang miskin membelanjakan sebagian pendapatan tambahan untuk makanan sedangkan orang kaya jauh lebih rendah (Agoes, 2003). Aridiyah, F. O., Rohmawati, N., \& Ririanty, M. (2015).

Faktor yang menyebabkan kurang gizi telah diperkenalkan UNICEF dan telah digunakan secara internasional, yang meliputi beberapa tahapan penyebab timbulnya kurang gizi pada anak balita, baik penyebab langsung, tidak langsung, dan pokok masalah.Pertama, penyebab langsung yaitu makanan dan penyakit infeksi yang mungkin diderita. Timbulnya gizi kurang bukan saja karena makanan yang kurang tetapi juga karena penyakit. Anak yang mendapat makanan yang cukup baik tetapi sering diserang diare atau demam, akhirnya dapat menderita gizi kurang. Sebaliknya anak yang makan tidak cukup baik maka daya tahan tubuhnya (imunitas) dapat melemah, sehingga mudah diserang penyakit infeksi, kurang nafsu makan dan akhirnya mudah terkena gizi kurang (Soekirman, 2000). Sehingga disini terlihat interaksi antara konsumsi makanan yang kurang dan infeksi merupakan dua hal yang saling mempengaruhi.

Menurut Schaible \& Kauffman (2007) hubungan antara kurang gizi dengan penyakit infeksi tergantung dari besarnya dampak yang ditimbulkan oleh sejumlah infeksi terhadap status gizi itu sendiri. Beberapa contoh bagaimana infeksi bisa berkontribusi terhadap kurang gizi seperti infeksi pencernaan dapat menyebabkan diare, HIV/AIDS,tuberculosis, dan beberapa penyakit infeksi kronis lainnya bisa menyebabkan anemia dan parasit pada usus dapat menyebabkan anemia.

Penyakit Infeksi disebabkan oleh kurangnya sanitasi dan bersih, pelayanan kesehatan dasar yang tidak memadai, dan pola asuh anak yang tidak memadai (Soekirman, 2000). Penyebab tidak langsung yaitu ketahanan pangan di keluarga, pola pengasuhan anak, serta pelayanan kesehatan dan kesehatan lingkungan, Rendahnya ketahanan pangan rumah tangga, pola asuh anak yang tidak memadai, kurangnya sanitasi lingkungan serta pelayanan kesehatan yang tidak memadai merupakan tiga faktor yang saling berhubungan. Makin tersedia air bersih yang cukup untuk keluarga serta makin dekat jangkauan keluarga terhadap pelayanan dan sarana kesehatan, ditambah dengan pemahaman ibu tentang kesehatan, makin kecil resiko anak terkena penyakit dan kekurangan gizi (Unicef, 1998). Sedangkan penyebab mendasar atau akar masalah gizi di atas adalah terjadinya krisis ekonomi, politik dan sosial termasuk bencana alam, yang mempengaruhi ketidakseimbangan antara asupan makanan dan adanyapenyakit infeksi, yang pada akhirnya mempengaruhi status gizi balita (Soekirman, 2000).

Gangguan gizi (Almatsier,2003) disebabkan oleh faktor primer dan sekunder. Faktor primer adalah bila susunan makanan seseorang salah dalam kuantitas dan atau kualitas yang disebabkan oleh kurangnya penyediaan pangan, kurang baiknya distribusi pangan, kemiskinan, ketidaktahuan, kebiasaan makan yang salah, dan sebagainya. Faktor sekunder meliputi semua factor yang menyebabkan zat-zat gizi tidak sampai di sel-sel tubuh setelah makan dikonsumsi. 


\section{KESIMPULAN DAN SARAN}

\section{Kesimpulan}

Menu seimbang dan pemeriksaan fisik kesehatan pada balita harus selalu dilakukan secara kontiniu untuk pertumbuhan dan perkembangan masa balita.

\section{Saran}

Berbagai upaya dapat dilakukan untuk mendapatkan balita yang status gizinya normal maka perlu dilaksanakan pemantauanstatus gizi secara intensif salah satunya di posyandu oleh ibu, dan

petugas kesehatan. Begitu juga dengan orangtua harus bekerja keras dalam mengasuh anak balita untuk lebih memperhatikan perkembangan dan pertumbuhan balita dengan cara mencari informasi dari tenagakesehatan maupun dari orang lain untuk memberikan makanan yang berkualitas.

\section{DAFTAR PUSTAKA}

Asosiasi Dietisien Indonesia (Asdi), Ikatan Dokter Anak Indonesia (IDAI) \& Persatuan Ahli Gizi Indonesia (PERSAGI). 2014. Penuntun Diet Anak.

Jakarta:Universitas Indonesia Press

Azria, C. R., \& Husnah. (2015). Pengaruh Penyuluhan Gizi Terhadap Pengetahuan dan Perilaku Ibu Tentang Gizi Seimbang Balita Kota Banda Aceh. Jurnal Kedokteran Syiah Kuala, 16(2), 87-92.

Badan Penelitian Dan Pengembangan. (2010). Riset Kesehatan Dasar. Riset Kesehatan Dasar. Https://Doi.Org/1 Desember 2013

Cut, R. Azria, \& Husnah. (2015). Pengaruh Penyuluhan Gizi Terhadap Pengetahuan dan Perilaku Ibu Tentang Gizi Seimbang Balita Kota Banda Aceh. Pengaruh Penyuluhan Gizi Terhadap Pengetahuandan Perilaku Ibu Tentang Gizi Seimbang Balita Kota Banda Aceh, 1(2016), 87-92.

Darmawan, F. H., Nur, E., \& Sinta, M. (2015). Hubungan Pengetahuan Dan Sikap Ibu Dengan Perilaku Pemberian Mp-Asi Yang Tepat Pada Bayi Usia 6-12 Bulan Jurnal Kawengian S E S, Murty Ekawaty M, \& Nova H Kapantow. (2015). Hubungan Antara Pengetahuan Ibu Tentang Gizi Dengan Status Gizi Anak Umur 1- 3 Tahun Di Desa Mopusi Kecamatan Lolayan Kabupaten Bolaang Mongondow Induk Sulawesi Utara. Jurnal E-Biomedik (Ebm), 3(2), 609-614.

Margawati, A., \& Astuti, A. M. (2018). Pengetahuan Ibu, Pola Makan Dan Status Gizi Pada Anak Stunting Usia 1-5 Tahun Di Kelurahan Bangetayu, Kecamatan Genuk, Semarang. Jurnal Gizi Indonesia, 6(2), 82. Https://Doi.Org/10.14710/Jgi.6.2.82-89

Munthofiah, S. (2010). Hubungan Antara Pengetahuan, Sikap, Dan Perilaku Ibu Dengan Status Gizi Anak Balita.

Oktarina, Z., \& Sudiarti, T. (2014). Faktor Risiko Stunting Pada Balita (24-59 Bulan) Di Sumatera. Jurnal Gizi Dan Pangan, 8(3), 177. 41

Setyaningsih, S. R., \& Agustini, N. (2014). Pengetahuan, Sikap , Dan Perilaku Ibu Dalam Pemenuhan Gizi Balita : Sebuah Survai. Jurnal Keperawatan Indonesia, 17(3), 94. 
Sinuhaji, Lidya Natalia Br. (2018). Efektifitas Penyuluan Dan Media Leaflet Terhadap Pengetahuan Dan Sikap Ibu Balita Tentang Gizi Buruk Di Dusun Vii Desa Bangun Rejo Kecamatan Tanjung Morawa Utara Tahun 2018, (2009)

Wachdani, R., Abidin, Z., \& Yaqin, M. A. (2012). Pengatur Pola Menu Makanan Balita Untuk Mencapai Status Gizi Seimbang Menggunakan Sistem Inferensi Fuzzy Metode Sugeno. Matics, (June 2016).

Widyakarya Nasional Pangan Dan Gizi Xi. (2018). Untuk Pencegahan Stunting Pola Konsumsi , Pengasuhan , Higienis Pribadi Dan Lingkungan. 